\title{
游荡性河流演变规律研究进展 及其河型归属探讨
}

\author{
解哲辉 ${ }^{1,2}$, 黄河清 $1^{*}$, 周园园 ${ }^{1}$, 张 敏 $1,2,3$ \\ (1. 中国科学院地理科学与资源研究所,陆地水循环与地表过程院重点实验室,北京 100101 ; \\ 2. 中国科学院大学, 北京 $100049 ; 3$. 黄河水利科学研究院泥沙研究所, 郑州 450003)
}

\begin{abstract}
摘 要: 游荡性河道在中国广泛分布, 其中以黄河下游上段最为典型, 但关于游荡性河型的归属问题尚存在很大争 议, 国际上多将游荡性河流归属为辫状河型。本文以黄河下游游荡性河道为典型案例, 系统总结了游荡性河流的 演变特征、主要影响因素和形成机理, 并从定义、成因、特征及河道形成过程方面, 将游荡与辫状河型的异同点进行 对比分析。得到以下启示: 游荡性河型是一种重要的河道型态, 与辫状河型在许多方面存在较明显差异。特别是 游荡河型主要发育于能量小于输沙需求的环境, 因而形态呈现不稳定特性, 但辫状河型不仅出现在能量较多的环 境, 而且也常在能量较小的环境中出现, 因而一部分具有稳定形态, 另一部分则表现出不稳定的特性, 因此, 有必要 对游荡性河道和辫状河道给予区分。最后对未来研究进行了展望, 提出应重视河型形成的内在机理, 对能量理论 进行发展及深化, 进一步系统性评价游荡性河道与辫状河道的异同性, 以解决游荡性河道的河型归属问题。
\end{abstract}

关键 词: 游荡河型; 竬状河型; 河型分类; 能量耗散; 研究进展

1 引言

自 Leopold 等(1957) 将冲积河流分为顺直 (straight)、弯曲 (meandering) 和辫状 (braided) 3 种河 型以来, 国内外学者对河型分类开展了深人系统性 的研究, 取得的主要进展如表 1 所示。在对典型河 型演变机理和形态特征进行深人分析的基础上,一 些定性或半定量指标及相关关系已用作区别不同 河型的判别条件(Leopold et al, 1957; Parker, 1976; Rust, 1978; van den Berg, 1995; Eaton et al, 2010)。 目前对多流路河流中的辫状与分汉(Lane, 1957; Chang, 1979a; Brice, 1982)、分汉与网状(Nanson et al, 1996; Makaske, 2001)、辫状与网状 (Rust, 1978; Miall, 1996; Makaske, 2001)等河型的归属问题讨论
较多。中国学者在河型分类方面也提出了一些较 有代表性的分类方案, 如方宗岱(1964)、钱宁等 (1987)、王随继等(1999)、王随继等(2000)、胡春宏等 (2005)、Xu等(2010), 并结合中国河流含沙量较大的 实际情况, 提出了区分不同河型的具体准则与方法 (谢鉴衡, 1982; 钱宁, 1985; 肖毅等, 2012)。Huang 等(2004)根据最小能量原理对河型成因给予了解 释, 认为当河流拥有的能量大于输送河道来沙所需 能量时, 河流将通过快速消耗能量的方式进行河道 形态调整。相反, 当河流拥有的能量小于输送河道 来沙所需能量时, 河道会通过泥沙淤积的方式进行 形态调整。以此物理推论为基础, Nanson等(2008) 提出了较为完善的河型分类方案(图 1), 并解释了稳 定性辫状和不稳定性辫状河型的成因。

收稿日期: 2016-02 ; 修订日期 : 2016-05。

基金项目: 国家自然科学基金重点项目(41330751); 国家国际科技合作专项项目(2013DFA91700); 国家自然科学基金项目 (51179181) [Foundation: Key Program of National Natural Science Foundation of China, No.41330751; International Science \& Technology Cooperation Program of China, No.2013DFA91700; National Natural Science Foundation of China, No.51179181]。

作者简介:解哲辉(1986-),女, 河北定州人,博士研究生,主要从事流水地貌研究,E-mail: xiezh.14b@igsnrr.ac.cn。

通讯作者:黄河清(1962-), 男, 宁夏中宁人, 研究员, 主要从事河流地貌及水土资源研究,E-mail: huanghq@igsnrr.ac.cn。

引用格式: 解哲辉, 黄河清, 周园园, 等. 2016. 游荡性河流演变规律研究进展及其河型归属探讨 [J]. 地理科学进展, 35(7): 898-909. [Xie Z H, Huang H Q, Zhou Y Y, et al. 2016. Progress on the study of fluvial process of wandering rivers and discussion about its channel pattern classification[J]. Progress in Geography, 35(7): 898-909.]. DOI: 10.18306/dlkxjz.2016.07.011 
表 1 主要河型分类方案

Tab.1 Main river channel pattern classifications

\begin{tabular}{|c|c|c|c|c|}
\hline 分类角度 & 代表文献 & 分类标准 & 划分方案 & 备注 \\
\hline \multirow[t]{2}{*}{ 沉积学 } & Schumm, 1963, 1977 & 河流泥沙运移的主导方式 & 悬移质、混合质、推移质 & 定性 \\
\hline & 王随继等, 1999 & 河道形态和沉积物特征 & 辫状、曲流、分汉、网状、直流 & 定性 \\
\hline \multirow[t]{5}{*}{ 水文地貌学 } & Leopold et al, 1957 & 河道坡度一流量关系 & 顺直、弯曲、辫状 & 半定量 \\
\hline & 方宗岱, 1964 & 河道平面形态的稳定性 & 江心洲河型、弯曲河型、摆动 & 定性 \\
\hline & Rust, 1978 & 辫状指数和弯曲度 & 顺直、弯曲、辫状、网状 & 定性 \\
\hline & Lane, 1957; Chang, 1979a & 流量一比降关系 & 顺直、弯曲、陡坡辫状、缓坡辫状 & 半定量 \\
\hline & Carling et al, 2014 & 水文过程和平面形态 & 单一河道、心滩辫状、岛屿辫状、网状 & 定性 \\
\hline \multirow[t]{5}{*}{ 水动力学 } & 钱宁, 1985 & 平面形态和水动力特性 & 顺直、弯曲、游荡、分汉 & 定性 \\
\hline & Schumm, 1985 & 水动力强度和泥沙运移特性 & $\begin{array}{l}\text { 顺直、蜿蜒、蜿蜒摆动、深泓蜿蜒摆动、游荡分 } \\
\text { 汉辫状、相对稳定分汊江心洲和网状河流等 }\end{array}$ & 半定量 \\
\hline & Huang et al, 2004 & 河谷比降一最小能坡的差异性 & 顺直、弯曲、游荡、辫状、分汉 & 半定量 \\
\hline & Nanson et al, 2008 & 河谷比降一最小能坡的差异性 & 阶梯深潭、顺直、弯曲、分汉、辫状、游荡 & 半定量 \\
\hline & Xu et al, 2010 & 水流来沙系数 & $\begin{array}{l}\text { 低泥沙浓度弯曲、高泥沙浓度弯曲、竬状、岛 } \\
\text { 屿河流 }\end{array}$ & 半定量 \\
\hline
\end{tabular}

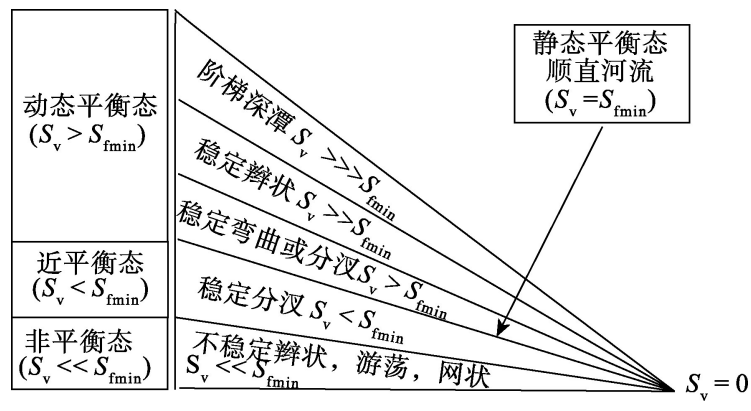

图 1 基于能坡的河型分类示意图 ${ }^{\mathbb{1}}$ (改自 Nanson et al, 2008)

Fig.1 Schematic diagram of river channel patterns in relation to valley slope and energy slope (after Nanson et al, 2008)

中国的黄河下游上部花园口一高村河段,国内 大多数研究认为其应属于一种独特的河型, 即游荡 型,英语分别称之为“wandering”(Huang et al, 2004; 王光谦等, 2005; 王卫红等, 2013)、“wandering braided”等(Xu, 1990; 陆中臣等, 2000), 但也有一些研究 将其归类为辫状河型(braided) (钱宁等, 1961; 王随 继, 2003; 吴保生等, 2003; Xia et al, 2008)。国际上 对这一河段演变规律方面的具体研究不多, 只是参 考国内的研究将其纳人传统的辫状河型范畴(Leopold et al, 1995)。除黄河下游高村以上河段外, 中国 许多地方, 特别是西北地区的塔里木河流域和黄河 宁蒙河段,游荡性河道广泛出现(王光谦等, 2005; 周丽艳等, 2016)。因此, 将中国的游荡性河道与国 际上采用的辫状河道两者进行对比研究, 对认识不
同河型的河道演变规律和制定有效的整治对策具 有十分重要的意义。

长期以来, 中国学者针对游荡性河道的河床演 变过程及其演化特征、河道形态调整规律及水沙响 应关系, 已开展了大量深人的系统研究, 取得了丰 硕成果。本文以黄河下游游荡型河段为典型案例, 对游荡性河流河道形态的形成、典型特征、不同水 沙条件下演化规律进行梳理,并从河型定义、典型 特征、成因和能量特征等方面对游荡性河道与辫状 河道的异同性进行分析,进而根据最新的河床演变 理论对这两种河型的成因进行总结,并对后续研究 进行展望。

\section{2 黄河下游游荡性河床演变规律研究 进展}

河床演变学是研究水流作用下河床形态及其 变化的学科(钱宁等, 1987)。水流、泥沙和河床三者 相互作用、相互影响,构成一个密不可分的整体, 牵 一发而动全身。黄河下游高村以上河段是典型的 游荡性河流,其演变规律一直是学术界关注的问 题。 20 世纪 60 年代以前, 黄河下游河道基本处于 自然演变时期, 人为干预较少。6 60 年代以后, 黄河 下游水沙过程呈现出 2 个新特征:一是水沙总量总 体呈减少趋势, 特别是龙羊峡水库修建以后,水沙

(1) $S_{\mathrm{v}}$ 代表河谷坡度, $S_{\mathrm{fmin}}$ 代表河流输送泥沙所需的最小坡度。 
量尤其是来沙量锐减, 小浪底水库运用后径流量稍 有增加。自小浪底水库运用以来, 黄河下游基本处 于清水下泄状态(申冠卿等, 2000; 胡春宏等, 2005; 姚文艺等, 2013; 李文文等, 2014)。二是水沙搭配 变异显著。上游龙羊峡水库调度运用后, 汛期来水 量锐减而来沙量减少不多, 因此形成小水带大沙的 情况。另外, 汛期大流量的洪水出现次数也显著减 少, 而中小流量的洪水则呈增多趋势(苏运启等, 2006; 黎云云等, 2014; 张敏等, 2016)。这些水沙变 异条件下游荡性河床如何演变引起了极为广泛的 关注(胡春宏等, 2005; 潘贤娣等, 2006; 夏军强等, 2008; 陈建国等, 2012)。本节主要从河道平面形 态、过水断面形态、河床纵向变化的统计分析、物理 与数学模拟及 $3 \mathrm{~S}$ 技术在黄河下游河床演变中的应 用方面, 对游荡性河道河床演变成果进行综述。

\section{1 河道平面形态演变}

河道平面形态的变化常采用主流摆幅、弯曲系 数、深泓弯曲系数、主槽宽和滩地面积等参数进行 描述。近期也有采用藕节特征值来刻画河道平面 形态的变化(韩琳等, 2010)。不同时期,游荡性河道 平面形态呈现出不同的特点。 20 世纪 60 年代以 前, 黄河下游游荡段河势变化尤为剧烈, 如 19331960 年, 伊洛河口附近的主槽摆动范围最大超过 $10 \mathrm{~km}$ (潘贤娣等, 2006)。1960年以后, 主槽摆动幅 度逐渐减小。1989-1994年花园口一东坝头的游荡 河段的河槽摆动范围约为 1949-1960 年的 45\% (潘 贤娣等, 2006)。同时期, 东坝头一高村的游荡河段 逐渐向弯曲方向发展, 1998 年河道弯曲系数已达 1.45(金德生等, 2000; 陆中臣等, 2000; 许畑心等, 2003)。小浪底水库运行后, 游荡段主流摆幅进一 步降低, 2000-2008 年主流摆幅约为 1960-1964 年的 16\% 34\% (陈建国等, 2012)。河道平面形态除花园 口一黑岗口河段仍具有较强的游荡特性外, 其余河 段的游荡性均明显减弱, 个别河段出现弯曲河道的 外形(苏运启等, 2006; 陈建国等, 2012)。其中夹河 滩一高村河段的河势已基本趋于稳定(王卫红等, 2012)。许多研究表明, 水库群运用“调水调沙” 和 “蓄清排浑”调度导致进人黄河下游水沙量减少是 河道游荡性减弱的主要原因(陆中臣等, 2000; 陈建 国等, 2012; 王卫红等, 2012), 河道整治工程对限制 河道摆动强度作用显著(吴保生等, 2003)。

\section{2 过水断面形态演变}

河道过水断面形态调整是冲积河流河床演变
的重要内容。不同时期的来水来沙量及水沙过程, 决定了河道横断面的调整形式和变化幅度,使得游 荡段断面形态的调整呈现出不同特点(潘贤娣等, 2006)。20世纪 60 年代,黄河下游游荡段的断面河 相关系散乱, 河道主槽变化幅度大且迅速, 以侧向移 动为主(钱宁等, 1965)。三门峡水库蓄水拦沙投人 运行造成下游游荡河道冲刷强烈; 改为滞洪排沙运 行后, 滩槽发生快速回淤; 进人蓄清排浑调度后, 主 槽淤积变缓。龙羊峡和李家峡水库投人运行后, 主 槽严重萎缩, 致使 1996年高村附近河道的平滩流量 已不足 $3000 \mathrm{~m}^{3} / \mathrm{s}$, 至 2002 年进一步减至 $1800 \mathrm{~m}^{3} / \mathrm{s}$ 。 小浪底水库投人运行后,游荡段河槽形态冲刷下切 与展宽并存(夏军强等, 2008), 但一些河段以下切为 主(李晓娟等, 2014; 李洁等, 2015), 主槽淤积态势得 到逐渐缓解(Chu, 2014)。

水沙关系变异及河道边界因素是黄河下游河 道断面形态发生调整的根本原因(姚文艺等, 2007)。断面形态调整对水沙关系变异的响应具有 非线性和滞后性 2 个典型特征(许畑心等, 2000; 梁 志勇等, 2005)。来沙系数太大(高含沙水流)或太小 (清水下泄)均可导致河槽冲刷(许昫心等, 2000)。 与同年水沙条件变化相比,平滩河槽断面变化与前 期若干年的水沙变化均值趋势逐渐一致化(梁志勇 等, 2005; 胡春宏等, 2006)。水沙关系的变异还导 致滩岸崩塌, 从而使得河道横向展宽(夏军强等, 2002), 滩岸崩退与滩岸稳定系数、河相系数和水沙 条件存在一定的定量关系(Xia et al, 2014; 李洁, 2015; 李晓娟等, 2015)。游荡性河段的河岸土体组 成和力学特性也是滩岸崩退的重要原因(Xia et al, 2008)。此外, 黄河下游自 20 世纪 50 年代以来, 开 展的大规模河道整治工程, 显著增强了河岸抗冲 性, 对河道断面形态的调整具有明显的约束作用 (潘贤娣等, 2006)。

\section{3 河床纵向演变}

纵剖面形态是河床在特定水沙条件下经历较 长时期调整的结果, 是河床纵向冲淤的直观反映。 有观点认为, 黄河下游纵剖面呈平行抬升趋势 (王 恺忱, 1982; 张仁等, 1985; 谢鉴衡, 1986; 贾绍凤, 1994; 陆中臣等, 2003), 但也有研究认为受水沙条 件影响,整个下游的河床以非同步抬升方式进行 (周文浩等, 1983; 潘贤娣等, 2006)。还有研究认为, 1987-1997 年间,黄河下游纵剖面有向 “S 型”发展的 趋势(王兆印等, 2006), 水沙过程的变异导致黄河下 
游上下河段河床调整不一致是剖面形态发生转变 的根本原因(许畑心, 2001; 梁志勇等, 2004; 王兆印 等, 2006)。夏军强等(2008)利用三次曲线拟合法图 绘了 1855 年以来 4 个时期的黄河下游主槽比降图, 四条剖面线在小浪底下游大约 $500 \mathrm{~km}$ 处相交, 并认 为这可能与河口河道不断向海延伸有关。

受不同时期水沙条件的影响,游荡性河道河床 纵向冲淤也具有阶段性。三门峡水库 1960 年蓄水 拦沙运行期(1960 年 9 月-1962 年 3 月), 黄河下游河 段发生严重冲刷, 其中游荡河段(花园口一高村)的 冲刷量占整个下游冲刷量的 $40 \%$ (潘贤娣等, 2006)。从 1965 年直到 1999 年小浪底水库运行前, 游荡段总体呈淤积态势。持续淤积可能主要与不 利于输沙的水沙条件有关(潘贤娣等, 2006)。然而, 受河道整治和水沙条件改变的影响,河床抬升速率 在不同时期存在较明显的差异, 1962-1970年,游荡 段河床抬升速率最快, 1986-2000年, 抬升较为缓慢 (Ma et al, 2012)。小浪底水库调水调沙运行后, 清 水下泄导致游荡段发生冲刷, 与 1999年相比,2010 年高村以上河段同流量水位下降1.82 2.05 m(万占 伟等, 2012)。但冲刷效率沿程递减, 花园口一夹河 滩河段冲刷明显大于夹河滩一高村河段(Chu, 2014; 尚红霞等, 2015)。分析表明,游荡性河段河 道形态调整受水沙条件影响最为密切, 不利的水沙 条件是黄河下游河床持续淤高的主要原因(潘贤娣 等, 2006; Chu, 2014)。目前, 游荡段发生沿程冲刷, 河道形态趋于稳定, 主要是由于小浪底水库下泄特 定的水沙过程。

\section{4 河工实验、数值模拟及 $3 \mathrm{~S}$ 技术在河床演变中的 应用}

为了精确、直观地揭示游荡性河床的演变规 律, 预测河道演变趋势, 物理模型试验、数值模拟和 $3 \mathrm{~S}$ 技术也广泛应用于游荡性河床演变研究中, 并取 得了丰硕成果。

河工模型实验是除实测资料分析之外最常用 的一种研究手段。由于其具有可重现历史状况、弥 补和扩充测验资料和进行多方案对比等优点, 在游 荡性河道理论研究(张红武等, 1996; 王明甫等, 2000)、河道整治(江恩惠, 2000; 齐璞等, 2011)及物 理模型设计(王光谦等, 2005)等方面得到了广泛应 用。但由于泥沙理论尚待完善, 物理模型设计中还 存在的模型相似、加沙和比尺等问题, 仍有待进一 步深化和完善(王光谦等, 2005)。
数值模拟是分析不同水沙运行条件及边界条 件下, 游荡性河道河势演化(黄金池等, 1999; 张红 武等, 2009; 钟德钜等, 2009)、纵向冲淤(孙东坡等, 2014; 夏军强等, 2015)及洪水演进过程(夏军强, 王 光谦, 张红武, 2003; 孙东坡等, 2009; 张防修等, 2014)。目前,使用一维及二维泥沙数值模型模拟 河床纵向变形已较为成熟,但由于游荡性河道边界 条件复杂, 横向变形强烈, 因此许多学者致力于分 析滩岸崩退、河道横向输沙等条件下,能同时反映 游荡性河道横向和纵向演变的数值模拟技术(夏军 强, 王光谦, 吴保生, 2003, 2004; 钟德钰等, 2009)。 然而由于泥沙问题的复杂性, 再加上数值模拟同时 涉及计算水动力学、泥沙运动力学和河床演变学, 而游荡性河段中关于这些基本学科的物理机理仍 不甚明确, 因此, 还有许多问题仍待解决(夏军强 等, 2004; 张明进等, 2011)。

$3 \mathrm{~S}$ 技术在游荡性河道平面形态研究方面具有 较多优势, 已取得了一系列的研究成果(刘学工等, 2012), 而其在研究河道断面形态方面仍处于尝试 阶段(刘学工等, 2008)。例如,陆中臣等(2000)通过 将航片与水文观测资料进行对比分析的方式, 对黄 河下游游荡段河道平面形态及其变化趋势进行了 预测; 李云驹等(2009)借助遥感和 GIS 技术, 对河道 治理后游荡段河势演变过程进行了研究; 韩琳等 (2010)对游荡段的藕节状演变特征进行了遥感监 测, 并对其与来水来沙条件及河道边界条件之间的 相关关系进行了探讨; 刘学工等(2008)根据基于遥 感影像建立的河相系数分析河道冲淤程度, 尝试对 黄河下游游荡段河道稳定性进行定量化, 但这一结 果的可靠性仍需要进一步验证。

\section{3 游荡与辫状河型的异同性}

\section{1 成因分析}

对于黄河下游游荡性河道, 钱宁等(1965)将河 床的持续堆积抬高和边界的不受约束作为其形成 的根本原因, 而将洪峰的暴涨猛落、泥沙易冲易淤、 含沙量变化幅度大等则作为加剧河道游荡强度的 辅助因素。谢鉴衡(1982)将游荡性河道主流摆动归 因于河床堆积抬高、洪水拉滩和沙滩移动 3 个主要 因素。事实上, 河道比降调整过程比较缓慢, 河道 边界稳定性的变异也较小,两者在一定时间内具有 相对稳定特性, 而河道来水来沙状况对流域状况和 
人类活动等因素则极为敏感,特别是对这些因素的 季节性及年际变化(Nilsson, 1976; 韩其为, 2003; 王 光谦, 2007)。因此, 剧烈的来水来沙条件是引发游 荡性河床形态调整的主动因素, 对这一河型的形成 与演变具有决定性作用(尹学良, 1993; 吴保生等, 2003)。当水沙条件发生显著改变后, 游荡性河道 有可能会发生河型转化(王卫红等, 2012)。

对于辫状河型而言, 早期研究认为, 比降决定 着辫状河道的形成,一定的水沙条件下, 辫状河型 往往与陡的河道比降相关 (Leopold et al, 1957; Schumm, 1985)。还有研究将辫状河道的形成与上 游来沙量及泥沙特性联系起来, 如含沙量过高和推 移质等(Carson, 1984; Paola, 2001)。强烈的推移质 淤积可能会导致河道中形成大片心滩, 从而迫使水 流沿心滩分汊, 形成辫状河道 (Ashmore, 1991, 2013)。近些年来, 植被对河型的影响受到广泛关 注(Millar, 2000; Gurnell, 2014)。植被主要是通过影 响滩岸的稳定性来影响河型(Coulthard, 2005; Tal et al, 2010)。植被发育稀少的河岸, 其抗冲性和对 水流的约束性越差, 越容易发育辫状河型。最近, Ashmore(2013)认为辫状河流发育于高能量, 河床粗 粘且植被较少发育的环境中。Surian(2015)认为当 河道存在非粘性物质、来沙过多和横向不受约束或 约束很小时, 就会形成辫状河道。综合来看, 辫状 河型的形成受到河道比降、水沙条件、边界条件和 植被等众多因素的影响, 但何种因素是辫状河型形 成的主要因素还有待进一步研究。

\section{2 典型演变特征分析}

黄河下游游荡性河道演变的典型特征主要有： (1)河身顺直, 河道平面形态散乱且变形强烈。河道 弯曲系数低, 高村以上游荡段内弯曲系数仅为 1.15 左右; 水流冲刷心滩或沿心滩分汉,形成多股水流, 且不断汇合与重新分汉, 造成河道主流迁徙不定。 由于抗冲性节点的存在, 游荡段河宽沿程宽窄相 间,形成扩张段和收缩段交替分布的藕节状形态。 (2)河道过水断面宽浅,主槽摆动强烈。1977年7月 8 日, 宽深比高达 3074(钱宁等, 1987), 2013 年汛后， 花园口一夹河滩河段河槽平均宽深比也有 391.52 (尚红霞等, 2015)。游荡段主槽摆动在年内存在季 节性差异。汛期摆动强度大于非汛期, 而且摆动速 度快。1954年 8 月的洪水中, 柳园口主槽一昼夜来 回摆动达 $6 \mathrm{~km}$ 之多(钱宁等, 1965)。2000-2008 年 花园口一夹河滩河段主流摆幅降低到 $345 \mathrm{~m}$ (陈建
国等, 2012)。(3)纵向淤积强烈。黄河下游长期处 于淤积抬升状态, 特别是游荡性河段, 在三门峡水 库建成前(1952-1960年), 该段淤积量甚至占到整个 下游淤积量的 90\%(钱宁等, 1987)。三门峡水库蓄 清排浑调水调沙运行期间(1985 年 10 月-1999年 10 月), 游荡段(花园口一高村)全断面淤积占下游比例 下降至约 17.49\%(潘贤娣等, 2006)。(4)心滩广泛发 育。心滩外形极不规则, 上端较高, 下端较低, 并缓 缓没人水中; 受洪水作用发生冲淤演变,洪水来时 心滩遭受切割分为破碎的几块, 洪水消退后泥沙落 淤又使其发展成较大的沙洲或与岸边相接, 形成河 漫滩; 心滩位置不固定, 且不断向下游移动, 移动速 度可达 $24.4 \mathrm{~m} / \mathrm{d}$ (钱宁等, 1965)。心滩物质组成以 粉砂和细砂为主, 且由于形状及位置均不固定, 植 被尚没得到发育。

辫状河流最早是指多股河道不断汇合及分开 的河道形态(Lane, 1957; Leopold et al, 1957), 是多 流路河道的总称。此后, 众多研究根据河道形态与 流量之间的关系、微地貌特征、河道平面形态特征 和植被状况对辫状河型给出了限定 (Rust, 1978; Brice, 1984; Schumm, 1985; Miall, 1996; Nanson et al, 1996)。有研究注意到在平滩等大流量条件下, 辫状河道心滩被淹没, 河道呈现出单流路河道特征 (Chitale, 1970; Kellerhals et al, 1976; Thorne et al, 1993)。Ashmore(1991)认为, 辫状河道是水流或推 移质沿河床不活跃部分的一种独特分汉, 不是心滩 表面简单的分合,与心滩是否出露水面没有必然联 系。此后的许多研究也认为其属于不稳定的多流 路河型 (Eaton et al, 2010; Ashmore, 2013; Surian, 2015)。还有研究将辫状河道分为心滩辫状和岛屿 辨状 2 种 (Schumm, 1985; Gurnell et al, 2000; Carling et al, 2014), 且 Carling 等(2014)认为前者属于单 流路河型,后者属于多流路河型。

通过对 2 种河型的典型特征进行对比可以发 现, 中国研究者对游荡性河道的形态特征及河床演 变规律认识较为清晰, 将其视为不稳定的多流路河 型。而辫状河道自 Leopold等(1957)提出至今, 其典 型河道形态特征在不同时期也不尽相同。有些研 究将辫状河流视为不稳定河流系统的代名词。也 有研究认为心滩辫状是单流路河型, 并用岛屿辫状 来描述较为稳定的河流系统(Carling et al, 2014)。 因此, 国外研究者对于辫状河道的河型属性还存有 争议。 


\section{3 河道泥沙输移特性分析}

泥沙过多是辫状河道和黄河下游游荡性河道 形成的重要原因(钱宁等, 1965; Carson, 1984; Surian, 2015)。对于辫状河道而言, 有研究认为, 辫状河 型与河流变化的推移质输沙量有关, 过多的推移质 是辫状河道形成的重要因素(Paola, 2001; Mueller et al, 2014)。而黄河下游游荡性河道的泥沙输移以 悬移质为主, 推移质所占比例一般不到 $10 \%$ (钱宁 等, 1965; 龙毓寒等, 2002)。根据钱宁(1965)于 20 世 纪 60 年代对黄河下游游荡段秦厂一带泥沙输移的 测算, 冲泻质在悬移质中所占比例达 $60 \%$, 泥沙输 移存在典型的“多来多排”现象。可见, 从河道泥沙 特性来看, 两者确实存在较显著的差别。

\section{4 形成过程分析}

就河道型态形成过程而言, 有学者注意到辫状 河道的形成并非是整个河段同时形成,而是通过部 分活动河道的不断迁移变化逐步达到的(Ashmore, 2001; Bertoldi et al, 2009; Egozi et al, 2009)。在黄 河下游游荡性河段内, 河道演变一般遵循“大水趋 中, 小水作弯” 的演变规律。虽然小水期内河道平 面形态亦缓慢发生改变,但由于局部水力因素的改 变, 在很短的时间内, 河道即可发生大规模的冲淤 变化, 河道外形甚至面目全非。因此河床变形呈现 强度大、变形速度快、影响距离深远的特性(钱宁 等, 1965)。游荡性河段形态对洪水的响应更加敏 感、迅速,一次大流量来水即可使其外形发生完全 改观。大幅度、高频率的河槽横向摆动更是游荡性 河流演变过程中的一个突出特点(钱宁等, 1965)。

\section{5 水流能量特征分析}

泥沙过多是黄河下游游荡性河道形成的重要 原因。当河道来沙量过多, 超过河道最大输沙能力 时, 河道发生淤积不可避免, 河床随之抬高, 在淤积 发展到一定程度时, 水流发生游荡。在上游来水来 沙条件相对稳定、河道没有大范围决口的情况下， 河道通过水流游荡获取的能量十分有限, 因此河道 会呈现出游荡的特性并得以长时期保持。坡度过 陡是辫状河道形成的重要因素。当河谷坡度相对 较陡时, 河流存在多余能量, 水流将通过多种方式 不断和外界进行能量交换, 消耗多余能量, 使得河 道达到动态平衡 (Huang et al, 2007; Nanson et al, 2008)。与泥沙过多形成的河型相比, 该类河道上 形成的河型极为稳定。

国际上许多针对河型成因的研究表明, 泥沙过
多或者河谷坡度过陡(Leopold et al, 1957; Parker, 1976; Chang, 1979b; Wang et al, 1989; Knighton, 1998; Millar, 2000; Surian, 2015)均可导致辫状河道 的形成。根据上段分析可知, 从能量消耗原理来 看,该两种成因下所形成的河型的稳定性会有很大 的差别。泥沙过多形成的辫状河型, 由于其河谷坡 度远小于输沙所需的最小能坡 $\left(S_{v}<<S_{\text {fmin }}\right)$, 河流无法 达到输沙平衡, 河道淤积不可避免, 属非平衡河流 系统。而河流坡度过陡形成的河型 $\left(S_{v}>>S_{\text {fnin }}\right)$, 水流 能够消耗多余能量来达到动态平衡, 因而河道形态 可维持长期稳定。因此,辫状河型与游荡河型的能 量消耗机理与特征有很大的不同。

\section{4 启示与展望}

以中国黄河下游游荡性河道为典型案例, 对游 荡型河流的时空演变特征、影响因素和形成机理等 方面的研究进行了系统梳理, 从定义、成因、特征、 河道形成过程和河流能量消耗的角度, 将游荡性河 型与传统的辫状河型进行了对比分析, 得到以下主 要启示:

(1) 多流路河流的分类问题一直是河型分类研 究中争议的焦点, 其中黄河下游游荡性河道多作为 争议的案例。游荡性河流作为一种独特的河型已 为国内大多数学者所认可,而辫状河型源于传统的 国外分类方案, 两者的分类标准有很大的差别, 前 者能够反映河流的运动特性, 而后者则偏重于考虑 河道的平面形态特征。

(2) 游荡性河道是一种重要的河型。中国学者 对于黄河下游游荡性河道河床演变特征及规律已 取得大量研究成果, 然而目前对黄河下游游荡性河 道的自动调整机理的认识还需进一步深化。

（3）黄河下游游荡性河道与辫状河型在定义、 成因、典型特征、形成过程、泥沙输移特性及能量消 耗机理等方面存在较明显差异。因此有必要对游 荡性河道和辫状河道的异同性进行深人系统分析。

(4) 从河流发育的能量机理方面来看,游荡性 河流主要产生于能量小于输沙所需的环境, 河道因 而大多不稳定, 是一种典型的非平衡态河流系统。 辫状河型既包括了能量较多、形态稳定的动态平衡 河流系统,也包括能量较小、形态多变的非平衡河 流系统。黄河下游游荡性河段长期以来一直承受 极为严重的泥沙淤积, 水流流路摆动极为频繁, 是 
最为典型的非平衡河流系统。

河型分类是一项极其复杂且艰巨的工作。特 别是对于游荡性河道而言, 既要深刻理解其形成的 独特性及河流演变规律, 又必须准确把握国内外河 型分类体系及其发展趋势。从目前的研究来看, 还 有一些问题有待深人研究: (1)系统评价游荡性河道 与辫状河道的异同性。游荡性河道和辫状河道是 国内外学者基于不同分类标准而形成的河型, 从前 文对两者的分析来看, 两者在许多方面确实存在显 著差别。如何对这两种河型进行系统评价, 对于准 确理解河型分类体系及河型演化规律至关重要。 (2)重视河型形成的内在机理。平面形态相似的两 种河型, 其形成的地貌动力学过程可能并不相同。 因此探究河型形成过程中各因素相互作用的内在 机理对于更好地进行河型分类非常重要。(3)能量 理论的发展及深化。基于能量原理的河流动力地 貌学理论的发展, 特别是对非平衡河流演变机理的 认识, 能为更精准的河型分类提供坚实的理论支 撑, 但目前对这一机理的认识还很不成熟, 需要进 一步的深化研究和广泛的实践检验。

\section{参考文献(References)}

陈建国, 周文浩, 陈强. 2012. 小浪底水库运用十年黄河下游 河道的再造床 [J]. 水利学报, 43(2): 127-135. [Chen J G, Zhou W H, Chen Q. 2012. Channel re- establishment of the lower Yellow River in ten years operation of Xiaolangdi Reservoir[J]. Journal of Hydraulic Engineering, 43 (2): 127-135.]

陈建国, 周文浩, 韩闪闪. 2015. 黄河小浪底水库拦沙后期运 用方式的思考与建议 [J]. 水利学报, 46(5): 574-583. [Chen J G, Zhou W H, Han S S. 2015. Ponderations and suggestions on operation mode of Xiaolangdi Reservoir in its second stage of sediment retaining[J]. Journal of Hydraulic Engineering, 46(5): 574-583.]

方宗岱. 1964. 河型分析及其在河道整治上的应用[J]. 水利 学报, (1): 1- 12. [Fang Z D. 1964. Hexing fenxi jiqi zai hedao zhengzhi shang de yingyong[J]. Journal of Hydraulic Engineering, (1): 1-12.]

韩琳, 张艳宁, 刘学工. 2010. 黄河下游河道藕节形态特征遥 感监测研究 [J]. 人民黄河, 32(10): 24-25, 28. [Han L, Zhang Y N, Liu X G. 2010. Study on characteristics of loins-root-joint shape channel of the lower Yellow River through remote sensing[J]. Yellow River, 32(10): 24-25, 28.]

韩其为. 2003. 水库淤积 [M]. 北京: 科学出版社. [Han Q W. 2003. Shuiku yuji[M]. Beijing, China: Science Press.]
胡春宏, 等. 2005. 黄河水沙过程变异及河道的复杂响应 [M]. 北京: 科学出版社. [Hu C H, et al. 2005. Huanghe shuisha guocheng bianyi ji hedao de fuza xiangying[M]. Beijing, China: Science Press.]

胡春宏, 陈建国, 刘大滨, 等. 2006. 水沙变异条件下黄河下 游河道横断面形态特征研究 [J]. 水利学报, 37(11): 1283- 1289. [Hu C H, Chen J G, Liu D B, et al. 2006. Studies on the features of cross section's profile in lower Yellow River under the conditions of variable incoming water and sediment[J]. Journal of Hydraulic Engineering, 37(11): 1283-1289.]

黄金池, 万兆惠. 1999. 黄河下游河床平面变形模拟研究 $[\mathrm{J}]$. 水利学报, (2): 13-18. [Huang J C, Wan Z H. 1999. Numerical simulation of riverbed horizontal variation for the lower reaches of Yellow River[J]. Journal of Hydraulic Engineering, (2): 13-18.]

贾绍风. 1994. 黄河下游河流纵剖面平行抬升的统计检验 [J]. 地理研究, 13(2): 1-10. [Jia S F. 1994. On the statistical test of the parallel raising of the profile of the lower reach Yellow River[J]. Geographical Research, 13(2): 110.]

江恩惠. 2000. 黄河下游游荡性河道整治模型试验研究 [J]. 人民黄河, 22(9): 22-24. [Jiang E H. 2000. Huanghe xiayou youdangxing hedao zhengzhi moxing shiyan yanjiu[J]. Yellow River, 22(9): 22-24.]

金德生, 张欧阳, 陈浩, 等. 2000. 小浪底水库运用后黄河下 游游荡性河段深泓演变趋势分析 [J]. 泥沙研究, (6): 5262. [Jin D S, Zhang O Y, Chen H, et al. 2000. Analysis of thalweg evolution tendency of the wandering reach in the lower Yellow River after Xiaolangdi Reservoir operation [J]. Journal of Sediment Research, (6): 52-62.]

黎云云, 畅建霞, 涂欢, 等. 2014. 黄河干流控制性梯级水库 联合运行对下游水文情势的影响 [J]. 资源科学, 36(6): 1183-1190. [Li Y Y, Chang J X, Tu H, et al. 2014. Impact of controlling cascade reservoir joint operation on hydrologic regimes in the lower Yellow River[J]. Resources Science, 36(6): 1183-1190.]

李洁, 夏军强, 邓珊珊, 等. 2015. 近期黄河下游游荡段滩岸 崩退过程及特点 [J]. 水科学进展, 26(4): 517-525. [ $\mathrm{Li} \mathrm{J}$, Xia J Q, Deng S S, et al. 2015. Recent bank retreat processes and characteristics in the braided reach of the lower Yellow River[J]. Advances in Water Science, 26(4): 517-525.]

李文文, 傅旭东, 吴文强, 等. 2014. 黄河下游水沙突变特征 分析 [J]. 水力发电学报, 33(1): 108-113. [Li W W, Fu X D, Wu W Q, et al. 2014. Study on runoff and sediment process variation in the lower Yellow River[J]. Journal of Hydroelectric Engineering, 33(1): 108-113.]

李晓娟, 夏军强, 李洁, 等. 2015. 黄河下游游荡段持续淤积 及冲刷时平滩河槽形态调整规律 [J]. 四川大学学报: 工 
程科学版, 47(1): 97-104. [Li X J, Xia J Q, Li J, et al. 2015. Variation in bankfull channel geometry in the LYR undergoing continuous aggradation and degradation[J]. Journal of Sichuan University: Engineering Science Edition, 47(1): 97-104.]

李晓娟, 夏军强, 张晓雷, 等. 2014. 近期黄河下游游荡段平 滩河槽形态变化计算[J]. 水力发电学报, 33(5): 86-92. [Li X J, Xia J Q, Zhang X L, et al. 2014. Recent variations of reach- scale bankfull channel geometry in the braided reach of lower Yellow River[J]. Journal of Hydroelectric Engineering, 33(5): 86-92.]

李云驹, 王志飞, 马浩录, 等. 2009. 基于 RS 与 GIS 的黄河下 游河势演变分析 [J]. 人民黄河, 31(4): 23, 26. [Li Y J, Wang Z F, Ma H L, et al. 2009. Jiyu RS yu GIS de Huanghe xiayou heshi yanbian fenxi[J]. Yellow River, 31 (4): 23, 26.]

梁志勇, 刘继祥, 张厚军. 2004. 从水沙条件探讨黄河下游上 下河段冲淤调整关系 [J]. 泥沙研究, (4): 15-19. [Liang Z Y, Liu J X, Zhang H J. 2004. Investigation on the sedimentation relation between the upper and lower reaches from the flow-sediment combination in the lower Yellow River[J]. Journal of Sediment Research, (4): 15-19.]

梁志勇, 杨丽丰, 冯普林. 2005. 黄河下游平滩河槽形态与水 沙搭配之关系 [J]. 水力发电学报, 24(6): 68-72. [Liang Z Y, Yang L F, Feng P L. 2005. Relations of channel geometry to water and sediment rate for the lower Yellow River [J]. Journal of Hydroelectric Engineering, 24(6): 68-72.]

刘学工, 韩琳, 张艳宁, 等. 2008. 黄河下游游荡型河段河相 遥感监测分析研究 $[\mathrm{J}]$. 人民黄河, 30(3): 4-6. [Liu X G, Han L, Zhang Y N, et al. 2008. Huanghe xiayou youdangxing heduan hexiang yaogan jiance fenxi yanjiu[J]. Yellow River, 30(3): 4-6.]

刘学工, 张艳宁, 韩琳, 等. 2012. 黄河下游河势遥感监测技 术研究 [M]. 北京: 中国水利水电出版社. [Liu X G, Zhang Y N, Han L, et al. 2012. Remote sensing monitoring technology for river regime of Yellow River downstream[M]. Beijing, China: China Water \& Power Press.]

龙毓骞, 张原锋. 2002. 用全沙观点研究黄河泥沙问题 [J]. 人 民黄河, 24(8): 28-30. [Long Y Q, Zhang Y F. 2002. Yong quansha guandian yanjiu huanghe nisha wenti[J]. Yellow River, 24(8): 28-30.]

陆中臣, 陈劭锋, 陈浩. 2000. 黄河下游游荡段河道平面形态 与河势变化趋势预测 [J]. 地理学报, 55(6): 729-736. [Lu Z C, Chen S F, Chen H. 2000. The evolutionary tendency forecast of channel morphology and river state of the wandering braided rivers in the lower Yellow River[J]. Acta Geographica Sinica, 55(6): 729-736.]

陆中臣, 周金星, 陈浩. 2003. 黄河下游河床纵剖面形态及其 地文学意义 [J]. 地理研究, 22(1): 30-38. [Lu Z C, Zhou J X, Chen H. 2003. River bed longitudinal profile morphol- ogy of the lower Yellow River and its implication in physiography[J]. Geographical Research, 22(1): 30-38.]

潘贤娣, 李勇, 张晓华, 等. 2006. 三门峡水库修建后黄河下 游河床演变 [M]. 郑州: 黄河水利出版社. [Pan X D, Li Y, Zhang X H, et al. 2006. Sanmenxia shuiku xiujian hou Huanghe xiayou hechuang yanbian[M]. Zhengzhou, China: The Yellow River Water Conservancy Press.]

齐璞, 孙赞盈, 齐宏海. 2011. 再论黄河下游游荡性河道双向 整治方案 [J]. 泥沙研究, (3): 1-9. [Qi P, Sun Z Y, Qi H H. 2011. Research on two-bank training strategy for wandering channels of lower Yellow River[J]. Journal of Sediment Research, (3): 1-9.]

钱宁. 1985. 关于河流分类及成因问题的讨论 [J]. 地理学报, 40(1): 1-10. [Chien N. 1985. On the classification and causes of formation of different channel patterns[J]. Acta Geographica Sinica, 40(1): 1-10.]

钱宁, 张仁, 周志德. 1987. 河床演变学 [M]. 北京: 科学出版 社. [Chien N, Zhang R, Zhou Z D. 1987. Hechuang yanbianxue[M]. Beijing, China: Science Press.]

钱宁, 周文浩. 1965. 黄河下游河床演变[M]. 北京: 科学出版 社. [Chien N, Zhou W H. 1965. Huanghe xiayou hechuang yanbian[M]. Beijing, China: Science Press.]

钱宁, 周文浩, 洪柔嘉. 1961. 黄河下游游荡性河道的特性及 其成因分析 [J]. 地理学报, 27: 1-27. [Chien N, Zhou W H, Hong R J. 1961. The characteristics and genesis analysis of the braided stream of the lower Yellow River[J]. Acta Geographica Sinica, 27: 1-27.]

尚红霞, 孙赞盈, 田世民. 2015. 2000-2013 年黄河下游河道 冲淤变化分析 [J]. 人民黄河, 37(8): 7-10. [Shang H X, Sun Z Y, Tian S M. 2015. Scouring and siltation characteristics in the lower Yellow River since 2000[J]. Yellow River, 37(8): 7-10.]

申冠卿, 张晓华, 李勇, 等. 2000. 1986 年以来黄河下游水沙 变化及河道演变分析[J]. 人民黄河, 22(9): 10-12. [Shen G Q, Zhang X H, Li Yong, et al. 2000. 1986nian yilai Huanghe xiayou shuisha bianhua ji hedao yanbian fenxi [J]. Yellow River, 22(9): 10-12.]

苏运启, 尚红霞, 李勇, 等. 2006. 小浪底水库对水沙的调控 及下游河道响应 [J]. 泥沙研究, (5): 28-32. [Su Y Q, Shang H X, Li Y, et al. 2006. Water-sediment regulation by the Xiaolangdi Reservoir and the response of the lower Yellow River[J]. Journal of Sediment Research, (5): 2832.]

孙东坡, 靳高阳, 李向阳, 等. 2009. MIKE21 在黄河下游洪水 演算中的应用研究 [J]. 人民黄河, 31(11): 27-28. [Sun D P, Jin G Y, Li X Y, et al. 2009. MIKE21 zai Huanghe xiayou hongshui yansuan zhong de yingyong yanjiu[J]. Yellow River, 31(11): 27-28.]

孙东坡, 刘明潇, 张晓雷, 等. 2014. 冲积性河流河床冲淤调 整对洪水泥沙过程的响应: 以黄河游荡型河段为例 $[\mathrm{J}]$. 
水科学进展, 25(5): 668-676. [Sun D P, Liu M X, Zhang $\mathrm{X}$ L, et al. 2014. Alluvial river adjusting response to the flood-sediment process: For the wandering reach of Yellow River as an example[J]. Advances in Water Science, 25(5): 668-676.]

万占伟, 安催花, 间朝晖. 2012. 小浪底水库对下游河道的冲 刷效果及趋势预测 [J]. 人民黄河, 34(5): 6-8. [Wan Z W, An C H, Yan Z H. 2012. Scouring effect and trend predicting of Xiaolangdi Reservoir on downstream river[J]. Yellow River, 34(5): 6-8.]

王光谦. 2007. 河流泥沙研究进展 [J]. 泥沙研究, (2): 64-81.

[Wang G Q. 2007. Advances in river sediment research [J]. Journal of Sediment Research, (2): 64-81.]

王光谦, 张红武, 夏军强. 2005. 游荡型河流演变及模拟 $[\mathrm{M}]$. 北京: 科学出版社. [Wang G Q, Zhang H W, Xia J Q. 2005. Youdangxing heliu yanbian ji moni[M]. Beijing, China: Science Press.]

王恺忱. 1982. 黄河河口与下游河道的关系及治理问题 [J]. 泥沙研究, (2): 1-10. [Wang K C. 1982. Relation between the lower Yellow River and the estuary and its regulation [J]. Journal of Sediment Research, (2): 1-10.]

王明甫, 陈立, 周宜林. 2000. 高含沙水流游荡型河道滩槽冲 淤演变特点及机理分析 [J]. 泥沙研究, (1): 1-6. [Wang M F, Chen L, Zhou Y L. Analysis on characters and mechanism of fluvial process of high sediment-laden flow in wandering channel[J]. Journal of Sediment Research, (1): 1-6.]

王随继. 2003. 黄河下游河型的特性及成因探讨 [J]. 地球学 报, 24(1): 73-78. [Wang S J. 2003. Channel pattern specialities and the formation of the lower reaches of the Yellow River[J]. Acta Geoscientia Sinica, 24(1): 73-78.]

王随继, 任明达. 1999. 根据河道形态和沉积物特征的河流 新分类 [J]. 沉积学报, 17(2): 240-246. [Wang S J, Ren M D. 1999. A new classification of fluvial rivers according to channel planform and sediment characteristics[J]. Acta Sedimentologica Sinica, 17(2): 240-246.]

王随继, 尹寿鹏. 2000. 网状河流和分汉河流的河型归属讨 论 [J]. 地学前缘, 7(S1): 79-86. [Wang S J, Yin S P. 2000. Discussion on channel patterns of anastomosing and anabranched rivers[J]. Earth Science Frontiers, 7(S1): 7986.]

王卫红, 李勇, 许志辉, 等. 2013. 大型水库调控对游荡性河 道整治工程适应性的影响 [J]. 泥沙研究, (6): 12-21. [Wang W H, Li Y, Xu Z H, et al. 2013. Impacts of regulation by a large reservoir on adaptability of channel training works on a wandering river[J]. Journal of Sediment Research, (6): 12-21.]

王卫红, 田世民, 孟志华, 等. 2012. 小浪底水库运用前后黄 河下游河道河型变化及成因分析 [J]. 泥沙研究, (1): 2331. [Wang W H, Tian S M, Meng Z H, et al. 2012. Evolu- tion processes of river pattern in lower Yellow River after commissioning of Xiaolangdi Reservoir[J]. Journal of Sediment Research, (1): 23-31.]

王兆印, 周静, 李昌志. 2006. 黄河下游水沙变化及河床纵横 断面的演变 [J]. 水力发电学报, 25(5): 42-45. [Wang Z Y, Zhou J, Li C Z. 2006. Water \& sediment load variation and development at longitudinal \& transversal profiles of the lower Yellow River[J]. Journal of Hydroelectric Engineering, 25(5): 42-45.]

吴保生, 马吉明, 张仁, 等. 2003. 水库及河道整治对黄河下 游游荡性河道河势演变的影响 [J]. 水利学报, (12): 1220. [Wu B S, Ma J M, Zhang R, et al. 2003. Effects of reservoir and training on river regime evolution of the braided reach in the lower Yellow River[J]. Journal of Hydraulic Engineering, (12): 12-20.]

夏军强, 王光谦, 吴保生. 2002. 黄河下游的滩岸侵蚀 [J]. 泥 沙研究, (3): 14-21. [Xia J Q, Wang G Q, Wu B S. 2002. Riverbank erosion in the lower Yellow River[J]. Journal of Sediment Research, (3): 14-21.]

夏军强, 王光谦, 吴保生. 2003. 黄河下游河床纵向与横向变 形的数值模拟: I 二维混合模型的建立 [J]. 水科学进 展, 14(4): 389-395. [Xia J Q, Wang G Q, Wu B S. 2003a. Numerical simulation for the longitudinal and lateral deformation of riverbed in the lower Yellow River, 1, establishment of a 2-D composite model[J]. Advances in Water Science, 14(4): 389-395.]

夏军强, 王光谦, 吴保生. 2004. 平面二维河床纵向与横向变 形数学模型 $[\mathrm{J}]$. 中国科学: 技术科学, 34(S1): 165-174. [Xia J Q, Wang G Q, Wu B S. 2004. Two-dimensional numerical modeling of the longitudinal and lateral channel deformations in alluvial rivers[J]. Science in China: Technological Sciences, 47(S1): 199-211.]

夏军强, 王光谦, 张红武. 2003. 黄河下游游荡型河段洪水演 进与河床变形过程的数值模拟 $[\mathrm{J}]$. 水动力学研究与进 展: A 辑, 18(3): 306-313. [Xia J Q, Wang G Q, Zhang H W. 2003. Numerical simulation of the flood routing and bed deformation processes in the wandering reach of the lower Yellow River[J]. Journal of Hydrodynamics: Series A, 18(3): 306-313.]

夏军强, 吴保生, 王艳平. 2008. 近期黄河下游河床调整过程 及特点 $[\mathrm{J}]$. 水科学进展, 19(3): 301-308. [Xia J Q, Wu B S, Wang Y P. 2008. Processes and characteristics of recent channel adjustment in the lower Yellow River[J]. Advances in Water Science, 19(3): 301-308.]

夏军强, 张晓雷, 邓珊珊, 等. 2015. 黄河下游高含沙洪水过 程一维水沙耦合数学模型 [J]. 水科学进展, 26(5): 686697. [Xia J Q, Zhang X L, Deng S S, et al. 2015. Modelling of hyperconcentrated floods in the lower Yellow River using a coupled approach[J]. Advances in Water Science, 26(5): 686-697.] 
肖毅, 邵学军, 周建银. 2012. 基于尖点突变的河型稳定性判 定方法 [J]. 水科学进展, 23(2): 179-185. [Xiao Y, Shao X J, Zhou J Y. 2012. A cusp catastrophe model for alluvial channel stability[J]. Advances in Water Science, 23(2): 179-185.]

谢鉴衡. 1982. “天然河流河床演变”专题总报告 [J]. 泥沙研 究, (1): 60-67. [Xie J H. 1982. “Tianran heliu hechuang yanbian” zhuanti zongbaogao[J]. Journal of Sediment Research, (1): 60-67.]

谢鉴衡. 1986. 黄河下游纵剖面变化及其治理问题 $[\mathrm{J}]$. 人民 黄河, (6): 3-8. [Xie J H. 1986. Changes in longitudinal profile of the lower Yellow River and problems related to its improvement[J]. Yellow River, (6): 3-8.]

许昫心. 2001. 黄河下游游荡河段清水冲刷时期河床调整的 复杂响应现象 [J]. 水科学进展, 12(3): 291-299. [Xu J X. 2001. Complex response in channel adjustment in the lower Yellow River during the period of clear-water scour [J]. Advances in Water Science, 12(3): 291-299.]

许昫心, 孙季. 2003. 黄河下游游荡河道萎缩过程中的河床 演变趋势 [J]. 泥沙研究, (1): 10-17. [Xu J X, Sun J. 2003. Tendency of channel change of the lower Yellow River during its shrinkage[J]. Journal of Sediment Research, (1): 10-17.]

许昫心, 张欧阳. 2000. 黄河下游游荡段河床调整对于水沙 组合的复杂响应 [J]. 地理学报, 55(3): 274-280. [Xu J X, Zhang O Y. 2000. Complicated fill-scour behaviors of the Huanghe River and the channel-forming processes[J]. Acta Geographica Sinica, 55(3): 274-280.]

姚文艺, 高航, 冷元宝, 等. 2007. 黄河下游河道萎缩成因分 析 [J]. 自然灾害学报, 16(4): 13-20. [Yao W Y, Gao H, Leng Y B, et al. 2007. Cause analysis of river channel shrinkage at lower reaches of the Yellow River[J]. Journal of Natural Disasters, 16(4): 13-20.]

姚文艺, 再大川, 陈江南. 2013. 黄河流域近期水沙变化及其 趋势预测 [J]. 水科学进展, 24(5): 607-616. [Yao W Y, Ran D C, Chen J N. 2013. Recent changes in runoff and sediment regimes and future projections in the Yellow River Basin[J]. Advances in Water Science, 24(5): 607616.]

尹学良. 1993. 河型成因研究[J]. 水利学报, (4): 1-11. [Yin X L. 1993. Formation of river patterns[J]. Journal of Hydraulic Engineering, (4): 1-11.]

张防修, 韩龙喜, 王明, 等. 2014. 主槽一维和滩地二维侧向 耦合洪水演进模型 [J]. 水科学进展, 25(1): 560-566. [Zhang F X, Han L X, Wang M, et al. 2014. Flood routing model with lateral coupling one-dimensional channel and two-dimensional floodplain simulation[J]. Advances in Water Science, 25(1): 560-566.]

张红武, 赵连军, 曹丰生. 1996. 游荡河型成因及其河型转化 问题的研究 [J]. 人民黄河, (10): 11-15, 61. [Zhang H W,
Zhao L J, Cao F S. 1996. Research of the cause of formation of wandering river model and its changes[J]. Yellow River, (10): 11-15, 61.]

张红武, 钟德钰, 张俊华, 等. 2009. 黄河游荡型河段河势变 化数学模型 $[\mathrm{J}]$. 人民黄河, 31(1): 20-22. [Zhang H W, Zhong D Y, Zhang J H, et al. 2009. Huanghe youdangxing heduan heshi bianhua shuxue moxing $[\mathrm{J}]$. Yellow River, 31(1): 20-22.]

张敏, 张明武, 何桂英, 等. 2016. 黄河下游不同峰型非漫滩 洪水冲刷效率分析 [J]. 人民黄河, 38(1): 1-5. [Zhang M, Zhang M W, He G Y, et al. 2016. Analysis of erosion efficiency in different flood wave type on non-floodplain flood in lower Yellow River[J]. Yellow River, 38(1): 1-5.] 张明进, 张华庆, 白玉川. 2011. 我国河流水流泥沙数值模拟 技术进展与应用 $[\mathrm{J}$ ]. 水道港口, 32(5): 329-335. [Zhang M J, Zhang H Q, Bai Y C. 2011. Development and applications of simulating technology for river flow and sediment in water transport engineering domain of China[J]. Journal of Waterway and Habor, 32(5): 329-335.]

张仁, 谢树楠. 1985. 废黄河的淤积形态和黄河下游持续淤 积的主要成因 [J]. 泥沙研究, (3): 1-10. [Zhang R, Xie S N. 1985. The depositional profile of the abandoned channel and the main cause of continuous aggradation of the lower Yellow River[J]. Journal of Sediment Research, (3): 1-10.]

钟德钰, 张红武, 张俊华, 等. 2009. 游荡型河流的平面二维 水沙数学模型 [J]. 水利学报, 40(9): 1040-1047. [Zhong D Y, Zhang H W, Zhang J H, et al. 2009. Two-dimensional numerical model of flow and sediment transport for wandering rivers[J]. Journal of Hydraulic Engineering, 40 (9): 1040-1047.]

周丽艳, 兰翔, 陈翠霞. 2016. 宁夏黄河干流河型及成因研究 [J]. 泥沙研究, (2): 52-56. [Zhou L Y, Lan X, Chen C X. 2016. Study on river pattern and formation mechanism of the Yellow River in Ningxia[J]. Journal of Sediment Research, (2): 52-56.]

周文浩, 范昭. 1983. 黄河下游河床近代纵剖面的变化[J]. 泥 沙研究, (4): 14-25. [Zhou W H, Fan Z. 1983. Changes of the recent longitudinal profile of the lower Yellow River [J]. Journal of Sediment Research, (4): 14-25.]

Ashmore P E. 1991. How do gravel-bed rivers braid[J]. Canadian Journal of Earth Sciences, 28(3): 326-341.

Ashmore P E. 2001. Braiding phenomena: Statics and kinematics[M]/Mosley M P. Gravel bed rivers. Christchurch, New Zealand: New Zealand Hydrological Society: 95120 .

Ashmore P E. 2013. Morphology and dynamics of braided rivers[M]//Shroder J F. Treatise on Geomorphology. San Diego, CA: Academic Press: 289-312.

Bertoldi W, Zanoni L, Tubino M. 2009. Planform dynamics of 
braided streams[J]. Earth Surface Processes and Landforms, 34(4): 547-557.

Brice J C. 1982. Stream channel stability assessment[R]. Washington DC: Federal Highway Administration, Offices of Research and Development: 42 .

Brice J C. 1984. Planform properties of meandering rivers[M]// Elliot C M. Proceedings of the conference- rivers' 83. New Orleans, LA: American Society of Civil Engineers: $1-15$.

Carling P, Jansen J, Meshkova L. 2014. Multichannel rivers: Their definition and classification[J]. Earth Surface Processes and Landforms, 39(1): 26-37.

Carson M A. 1984. The meandering-braided river threshold: A reappraisal[J]. Journal of Hydrology, 73(3-4): 315-334.

Chang H H. 1979a. Geometry of rivers in regime[J]. Journal of the Hydraulics Division, 105(6): 691-706.

Chang H H. 1979b. Minimum stream power and river channel patterns[J]. Journal of Hydrology, 41(3-4): 303-327.

Chitale S V. 1970. River channel patterns[J]. Journal of Hydraulics Division, 96(1): 201-221

Chu Z X. 2014. The dramatic changes and anthropogenic causes of erosion and deposition in the lower Yellow (Huanghe) River since 1952[J]. Geomorphology, 216: 171-179.

Coulthard T J. 2005. Effects of vegetation on braided stream pattern and dynamics[J]. Water Resources Research, 41 (4): 1-9.

Eaton B C, Millar R G, Davidson S. 2010. Channel patterns: Braided, anabranching, and singlethread[J]. Geomorphology, 120: 353-364.

Egozi R, Ashmore P. 2009. Experimental analysis of braided channel pattern response to increased discharge[J]. Journal of Geophysical Research, 114(F2): F02012.

Gurnell A. 2014. Plants as river system engineers[J]. Earth Surface Processes and Landforms, 39(1): 4-25.

Gurnell A, Petts G E, Harris N, et al. 2000. Large wood retention in river channels: The case of the Fiume Tagliamento, Italy[J]. Earth Surface Processes and Landforms, 25: 255-275.

Huang H Q, Chang H H, Nanson G C. 2004. Minimum energy as the general form of critical flow and maximum flow efficiency and for explaining variations in river channel pattern[J]. Water Resources Research, 40(4): 1-13.

Huang H Q, Nanson G C. 2007. Why some alluvial rivers develop an anabranching pattern[J]. Water Resources Research, 43(7): 1-14.

Kellerhals R, Church M, Bray I D. 1976. Classification and analysis of river processes[J]. Journal of the Hydraulics Division, 102: 813-829.

Knighton A D. 1998. Fluvial forms and processes: A new per-
spective[M]. London, UK: Arnold.

Lane E W. 1957. A study of the shape of channels formed by natural streams flowing in erodible material[M]. Omaha, NE: U.S. Army Corps of Engineers, Missouri River Diversion.

Leopold L B, Wolman M G. 1957. River channel patterns: Braided, meandering, and straight[R]. Washington: US Government Printing Office.

Leopold L B, Wolman M G, Miller J P. 1995. Fluvial processes in geomorphology[M]. New York: Dover Publications.

Ma Y X, Huang H Q, Nanson G C, et al. 2012. Channel adjustments in response to the operation of large dams: The upper reach of the lower Yellow River[J]. Geomorphology, 147-148: 35-48.

Makaske B. 2001. Anastomosing rivers: A review of their classification, origin and sedimentary products[J]. Earth-Science Reviews, 53(3-4): 149-196.

Miall A D. 1996. The geology of stratigraphic sequences[M]. Berlin, Germany: Springer-Verlag.

Millar R G. 2000. Influence of bank vegetation on alluvial channel patterns[J]. Water Resources Research, 36(4): 1109-1118.

Mueller E R, Pitlick J. 2014. Sediment supply and channel morphology in mountain river systems: 2 . Single thread to braided transitions[J]. Journal of Geophysical Research: Earth Surface, 119(7): 1516-1541.

Nanson G C, Huang H Q. 2008. Least action principle, equilibrium states, iterative adjustment and the stability of alluvial channels $[\mathrm{J}]$. Earth Surface Processes and Landforms, 33(6): 923-942.

Nanson G C, Knighton A D. 1996. Anabranching rivers: Their cause, character and classification[J]. Earth Surface Processes and Landforms, 21(3): 217-239.

Nilsson B. 1976. The influence of man's activities in rivers on sediment transport[J]. Nordic Hydrology, 7(3): 145-160.

Paola C. 2001. Modelling stream braiding over a range of scales[M]. Wellington, New Zealand: New Zealand Hydrological Society: 11-46.

Parker G. 1976. On the cause and characteristic scales of meandering and braiding in rivers[J]. Journal of Fluid Mechanics, 76(3): 457-480.

Rust B R. 1978. A classification of alluvial channel systems [M]//Miall A D. Fluvial sedimentology. Calgary, Canada: Canadian Society of Petroleum Geologists: 187-198.

Schumm S A. 1963. A tentative classification of alluvial river channels[M]. Washington: United States Geological Survey: 477.

Schumm S A. 1977. The fluvial system[M]. New York: John Wiley \& Sons.

Schumm S A. 1985. Patterns of alluvial rivers[J]. Annual Re- 
view of Earth and Planetary Sciences, 13: 5-27.

Surian N. 2015. Fluvial processes in braided rivers[M]//Roweinski P. Rivers-physical, fluvial and environmental processes. Berlin, Germany: Springer: 403-425.

Tal M, Paola C. 2010. Effects of vegetation on channel morphodynamics: Results and insights fromlaboratory experiments[J]. Earth Surface Processes and Landforms, 35: 1014-1028.

Thorne C R, Russell A P G, Alam M K. 1993. Planform pattern and channel evolution of the Brahmaputra River, Bangladesh[J]. Geological Society, 75: 257-276.

van den Berg J H. 1995. Prediction of alluvial channel pattern of perennial rivers[J]. Geomorphology, 12(4): 259-279.

Wang S, Zhang R. 1989. Cause of formation of channel patterns and pattern prediction[C]//Proceedings of the XXIIIth IAHR congress. Ottawa, Canada: IAHR: B131-
B136.

Xia J Q, Li T, Li X J, et al. 2014. Daily bank erosion rates in the lower Yellow River before and after dam construction $[\mathrm{J}]$. Journal of the American Water Resources Association, 50(5): 1325-1337.

Xia J Q, Wu B S, Wang Y P, et al. 2008. An analysis of soil composition and mechanical properties of riverbanks in a braided reach of the lower Yellow River[J]. Chinese Science Bulletin, 53(15): 2400-2409.

Xu J X. 1990. Areal distribution of wandering braided and stable braided river channel patterns in China[J]. Chinese Science Bulletin, 35(21): 1816-1821.

Xu J X, Yan M. 2010. Discrimination of channel patterns for alluvial rivers based on the sediment concentration to water discharge ratio[J]. Zeitschrift für Geomorphologie, 54 (1): 111-125.

\title{
Progress on the study of fluvial process of wandering rivers and discussion about its channel pattern classification
}

\author{
XIE Zhehui ${ }^{1,2}$, HUANG Heqing ${ }^{1 *}$, ZHOU Yuanyuan ${ }^{1}$, ZHANG Min $^{1,2,3}$ \\ (1. Key Laboratory of Water Cycle and Related Land Surface Processes, Institute of Geographic Sciences and \\ Natural Resources Research, CAS, Beijing 100101, China; 2. University of Chinese Academy of Sciences, Beijing \\ 100049, China; 3. Yellow River Institute of Hydraulic Research, Zhengzhou 450003, China)
}

\begin{abstract}
Wandering rivers frequently occur in China, especially in northern China, with the wandering reach of the lower Yellow River as the most typical case. However, controversy concerning their channel pattern classification remains. While such rivers are widely regarded as wandering or wandering-braided channel in China, they are categorized as braiding rivers largely by the international geomorphological community. In this article, the wandering reach of the lower Yellow River is taken as an example and the evolutionary characteristics of channel morphology is summarized, focusing on the factors influenced the channel evolution in different periods. Based on the summary, a comparison is made between braiding and wandering rivers, including their channel definitions, morphological features, sediment characteristics, forming processes, and energy expenditure features. Especially, the wandering channel pattern mainly develops in a low energy slope environment that is far less than the minimum energy slope required for transporting sediment load. So it usually presents unstable features. The braided channel pattern can exist where river energy is lower or higher than the minimum energy slope. Therefore, it is essential to distinguish these two channel patterns. The article also discusses prospects for studies in the future and points out that focusing on the physical mechanisms for channel formation, developing and refining the energy theory, and examining the differences and similarities of wandering channel and braided channel systematically can help to solve the problem of classifiying wandering rivers.
\end{abstract}

Key words: wandering rivers; braiding rivers; channel pattern classification; energy expenditure mechanism; research progress 